\title{
LITERASI KEUANGAN SYARIAH MELALUI MEDIA EDUKATIF UNTUK ANAK USIA SEKOLAH DASAR di SD MUHAMMADIYAH SURABAYA
}

Arin Setiyowati ${ }^{1}$, Dian Lailatullailia ${ }^{2}$

${ }^{1}$ Prodi Perbankan Syariah FAI Universitas Muhammadiyah Surabaya

${ }^{2}$ Mahasiswa Prodi Perbankan Syariah FAI Universitas Muhammadiyah Surabaya

Arin.st@fai.um-surabaya.ac.id ${ }^{1}$, dianlailatullailia@gmail.com²

Published : April 2020

\begin{abstract}
Abstrak
Kegiatan pengabdian kepada masyarakat ini dilaksanakan sebagai upaya untuk mengedukasi keuangan syariah pada anak usia sekolah dasar di lingkungan SD Muhammadiyah Surabaya melalui kegiatan literasi keuangan syariah dengan menggunakan media edukatif. Hal ini dilatarbelakangi dengan kenyataan bahwa kegiatan edukasi yang dilakukan selama ini untuk meningkatkan literasi keuangan syariah masih belum tersosialisasi dengan baik. Dan belum massif dalam menyentuh kalangan anak usia sekolah dasar. SD Muhammadiyah Surabaya yang diwakili oleh SD Muhammadiyah 8, 19 dan 24 Surabaya merupakan representasi dari sekolah dasar bernafaskan Islam yang dikelola oleh non-pemerintahan. Sehingga menjadi penting untuk mengawali literasi keuangan syariah bagi anak usia sekolah dasar sejak dini, khususnya melalui lembaga pendidikan formal Islam dengan media pembelajaran yang edukatif dan menyenangkan. Sehingga muatan yang ingin ditransformasikan dapat tersampaikan dengan mudah. Materi yang disampaikan adalah pengenalan konsep dasar keuangan syariah, ragam lembaga keuangan syariah dan akad-akad dalam transaksi yang digunakan dalam keuangan syariah. Kegiatan pengabdian dilaksanakan dalam bentuk sosialisasi dan permainan yang menarik. Kegiatan pengabdian telah dilaksanakan dalam beberapa tahap; koordinasi persiapan pelaksanaan, pelaksanaan kegiatan edukasi, dan kegiatan evaluasi kegiatan. Kegiatan pengabdian diikuti 30 siswa-siswi SD Muhammadiyah 8, 19 dan 24 Surabaya. Kegiatan pengabdian kepada masyarakat dapat meningkatkan literasi keuangan syariah peserta. Hal ini ditunjukkan dengan semakin pahamnya peserta mengenai konsep keuangan syariah, lembaga keuangan syariah dan akad- akad yang digunakan untuk pengembangan produk lembaga keuangan syariah.
\end{abstract}

Kata Kunci: Literasi Keuangan Syariah, Media Edukatif, Anak Usia SD, SD Muhammadiyah Surabaya 


\section{PENDAHULUAN}

Pada 2016, OJK (Otoritas Jasa Keuangan) merilis hasil survey tentang tingkat literasi dan inklusi keuangan syariah berada di angka 8,11 persen, sedangkan indeks inklusi keuangan syariah mencapai angka 11,06 persen. Hal tersebut menunjukkan bahwa pemahaman masyarakat atas layanan dan produk keuangan syariah masih rendah. Tingkat literasi keuangan syariah yang rendah tersebut memberikan dampak pada rendahnya pangsa pasar khususnya perbankan syariah. Yakni mencapai angka 5,12 persen, lebih rendah bila dibandingkan dengan pangsa pasar perbankan konvensional. (Said and Amiruddin 2017)

Adapun market share pasar perbankan syariah sudah menembus angka 5,67\%. (Subardi, Hani Meilita Purnama, Yuliafitri 2019)Kondisi tersebut tentu menjadi tantangan bagi perbankan syariah. Mengingat bahwa Indonesia merupakan Negara dengan mayoritas berpenduduk Muslim terbesar di dunia. Namun, tingkat literasi dan inklusi keuangan syariah tergolong rendah. Artinya, Islam hanya sebagai identitas dan ritual ibadah, belum mampu menjadi way of life bagi umat Muslim.

Adapun preferensi pada keuangan syariah yang menjadi perhatian Kunt, Klapper dan Randall (2013) mengklasifikasikan Muslim kedalam tiga kategori sehubungan dengan preferensi terhadap keuangan Islam atau konvensional, yaitu: (i) Muslim yang menolak untuk menggunakan produk keuangan konvensional karena menganggap melanggar Syariat Islam, (ii) Muslim yang menggunakan atau akan menggunakan kredit konvensional tetapi ada kemungkinan beralih ke pembiayaan syariah jika lebih banyak tersedia atau ditawarkan dengan hargayang kompetitif, dan (iii) Muslim yang menggunakan atau akan menggunakan kredit konvensional dan akan terus menggunakannya sekalipun harganya kompetitif dengan produk Syariah. (Setiawati, 2015)(Kusumadewi, Yusuf, and Si, M 2019)

Untuk dapat meningkatkan literasi keuangan, maka diperlukan edukasi keuangan yang baik. Hogarth dkk. (2003) dalam Ekonomi Pembangunan Syariah mengatakan bahwa proses edukasi keuangan dianggap metode paling efektif untuk meningkatkan literasi keuangan terhadap masyarakat. Adapun edukasi keuangan syariah yang efektif dan memiliki kekuatan mendasar untuk dapat terimplentasikan pada masyarakat adalah dengan melakukan literasi keuangan syariah pada pendidikan anak usia dasar. (Asyhad, M dan Handono 2017)

Mengapa demikian? Dalam Undang-undang No. UU No. 20 Th 2003, pasal 17 ayat 1, 2 disebutkan : “(1) Pendidikan dasar merupakan jenjang pendidikan yang melandasi jenjang pendidikan menengah. (2) Pendidikan dasar berbentuk sekolah dasar (SD) dan madrasah ibtidaiyah (MI) atau bentuk lain yang sederajat serta sekolah menengah pertama (SMP) dan madrasah tsanawiyah (MTs), atau bentuk lain yang sederajat. Artinya, usia-usia anak pada pendidikan dasar khususnya usia SD merupakan masa golden age dalam pembentukan pemikiran dan karakter untuk masa depan. (Asyhad, M dan Handono 2017)

Adapun term keuangan syariah adalah bagian dari aktifitas ekonomi. Dan menjadi lazim bagi seorang Muslim untuk tau, paham dan bersedia menjalankan aktifitas pemenuhan kebutuhannya dengan cara Islami, salah satunya dengan menggunakan fasilitas keuangan syariah. Edukasi atas keuangan syariah perlu digalakkan sejak dini agar kalangan muda 
yang masih duduk di bangku sekolah mengerti bagaimana cara mengelola keuangan secara bijak dan sesuai dengan kebutuhan literate dengan perbankan syariah.

Jauh sebelum itu, Naser et. al (1999) menemukan bahwa di Yordania 70 persen Muslim memilih menggunakan jasa keuangan syariah karena sesuai kepentingan agamanya, bukan karena mereka mengetahui penuh seluk-beluk produk keuangan Islam. Hal ini menunjukkan begitu pentingnya pemahaman literasi keuangan dalam kehidupan masyarakat muslim.(Subardi, Hani Meilita Purnama, Yuliafitri 2019)

Berangkat dari rasa keprihatinan atas tingkat literasi keuangan syariah yang masih minim inilah perlu adanya sebuah inovasi untuk melakukan pembelajaran (edukasi) dengan sebuah media yang menarik dan familiar dengan masyarakat umum khususnya anak usia sekolah dasar (SD). Melalui kegiatan literasi keuangan syariah ini penulis bermaksud untuk mengedukasi pada anak usia sekolah dasar tentang keuangan syariah sejak dini, sehingga Sehingga kedepannya dapat dapat meningkatkan inklusi keuangan syariah untuk mewujudkan ekonomi yang Islami.

Mengingat obyek edukasi ini adalah anak usia $\mathrm{SD}$, oleh karena itu tim penulis menginisiasi pembelajaran yang mudah untuk mengenalkan keuangan syariah kepada masyarakat umum khususnya anak usia SD berupa media-media edukatif diantaranya kartu si-akad, ular tangga, Komik Pintar Bank Syariah yang mana kontenkonten dalam media edukasi tersebut berisi tentang edukasi kegiatan-kegiatan berekonomi syariah seperti menabung, meminjam dan apa saja yang berhubungan dengan kegiatan bank syariah.

\section{TINJAUAN PUSTAKA}

\section{Literasi Keuangan Syariah}

Literasi Keuangan dapat diartikan sebagai kombinasi kesadaran, pengetahuan, keterampilan, sikap dan perilaku yang diperlukan untuk membuat keputusan keuangan yang sehat dan akhirnya mencapai kesejahteraan keuangan individu.

\section{National Institute for Literacy}

Istilah ini mendefinisikan literasi sebagai "kemampuan individu untuk membaca, menulis, berbicara, meng- hitung dan memecahkan masalah pada tingkat keahlian yang diperlukan dalam pekerjaan, keluarga dan masyarakat.6 Sedangkan keuangan menurut Kamus Besar Bahasa Indonesia adalah segala sesuatu yang bertalian dengan uang. Ridwan dan Inge (2003), mendefinisikan keuangan sebagai ilmu dan seni dalam mengelola uang yang mempengaruhi kehidupan setiap orang dan setiap organisasi. Keuangan berhubungan dengan proses, pasar, lembaga, dan instrumen yang terlibat dalam transfer uang diantara individu maupun antara bisnis dan pemerintah.

Literasi keuangan (financial literacy), menurut buku podoman Strategi Nasional Literasi Keuangan Indonesia, adalah rangkaian proses atau aktivitas untuk meningkatkan pengetahuan (knowledge), keyakinan (confidence) dan ketrampilan (skill) konsumen dan masyarakat luas sehingga mereka mampu mengelola keuangan yang lebih baik.

Menurut Isnuhardi, Literasi keuangan adalah suatu kombinasi kesadaran, pengetahuan, sikap dan tingkah laku yang dibutuhkan. untuk membuat keputusan-keputusan keuangan yang pada akhirnya mencapai kemakmuran individu. Adapun kata syariah merupakan hokum agama yang diamalkan menjadi perbuatan-perbuatan, 
upacara yang bertalian dengan agama Islam. Dapat dipahami bahwa literasi keuangan syariah adalah kecakapan atau kesanggupan seseorang dalam hal pemahaman dan penerapan keuangan yang dibutuhkan dalam kehidupan sesuai dengan nilai-nilai agama Islam sehingga mampu mengelola keuangan yang lebih baik dan mensejahterakan kehidupan lahir dan batin.

Berdasarkan pengertian tersebut, dapat disimpulkan bahwa konsumen produk dan jasa keuangan maupun masyarakat luas diharapkan tidak hanya mengetahui dan memahami lembaga jasa keuangan serta produk dan jasa keuangan, melainkan juga dapat mengubah atau memperbaiki prilaku masyarakat dalam pengelolaan keuangan sehingga mampu meningkatkan kesejahteraan mereka. (Subardi, Hani Meilita Purnama, Yuliafitri 2019)

Dalam konteks pembangunan literasi keuangan syariah dapat diartikan bahwa konsumen produk dan jasa keuangan syariah maupun masyarakat luas diharapkan tidak hanya mengetahui dan memahami lembaga jasa keuangan syariah serta produk dan jasa keuangan syariah, melainkan juga dapat mengubah atau memperbaiki prilaku masyarakat dalam pengelolaan keuangan secara syariah sehingga mampu meningkatkan kesejahteraan mereka.

Dalam literasi dikenal 3 kategori pengelompokan tingkat literasi keuangan yaitu well literate, sufficient literate, dan less literate. Kategori well literate berarti masyarakat memiliki pengetahuan dan keyakinan tentang lembaga jasa keuangan serta produk jasa keuangan, termasuk fitur, manfaat dan risiko, hak dan kewajiban terkait produk dan jasa keuangan, serta memiliki keterampilan dalam menggunakan produk dan jasa keuangan. Sedangkan kategori sufficient literate berarti masyarakat memiliki pengetahuan dan keyakinan tentang lembaga jasa keuangan serta produk dan jasa keuangan, termasuk fitur, manfaat dan risiko, hak dan kewajiban terkait produk dan jasa keuangan. Kategori less literate artinya masyarakat yang hanya memiliki pengetahuan tentang lembaga jasa keuangan, produk dan jasa keuangan, dan terakhir kategori not literate yang berarti masyarakat tidak memiliki pengetahuan dan keyakinan terhadap lembaga jasa keuangan serta produk dan jasa keuangan, serta tidak memiliki keterampilan dalam menggunakan produk dan jasa keuangan (http://www.ojk. go.id).(Kusumadewi, Yusuf, and Si, M 2019)

\section{METODE PENELITIAN}

Keseluruhan aktivitas pengabdian literasi keuangan syariah disesuaikan tipe media edukasi dengan menggunakan metode yang disesuaikan dengan tujuan yang diharapkan. Yakni melalui beberapa tahapan, sebagai berikut:

1) Kegiatan awal dan persiapan ; dilakukan oleh tim pengabdi dengan beberapa kepala sekolah dan guru SD Muhammadiyah di Surabaya sebagai tempat pelaksanaan kegiatan untuk berkoordinasi awal pelaksanaan kegiatan. Hal yang dikoordinasikan di antaranya adalah tempat pelaksanaan kegiatan dan delegasi masing-masing sekolah yang ada di SD Muhammadiyah 19 Bahari Keputih, SD Muhammadiyah 8, SD Muhammadiyah 24 Surabaya. 
2) Pelaksanaan Kegiatan.

Tujuan darikegiataniniadalah meningkatkan literasi keuangan syariah anak usia sekolah dasar melalui media edukatif di lingkungan SD Muhammadiyah Surabaya yang diwakili SD Muhammadiyah, 19, 8, 24 Surabaya. Kegiatan yang dilakukan oleh tim pengabdi adalah dengan memainkan media edukatif dibarengi dengan edukasi tentang keuangan syariah pada anak-anak usia sekolah dasar Kegiatan edukasi dilanjutkan dengan kegiatan sharing dan diskusi mengenai materi yang telah disampaikan dan pengetahuan lainnya.

3) Evaluasi kegiatan.

Tujuan dari kegiatan ini untuk diskusi dan evaluasi dari semua tahapan kegiatan yang telah dilakukan serta rencana kedepan kelanjutan dari kegiatan pengabdian ini. Evaluasi kegiatan pengabdian akan dilakukan setiap akhir tahapan kegiatan pengabdian dengan memberikan penilaian secara langsung (direct observation), yaitu diberlakukan pada sesaat setelah kegiatan pengabdian dilaksanakan. Supaya dapat dilakukan perbaikan. Indikator keberhasilan pelaksanaan kegiatan pengabdian dengan perubahan (penambahan) pemahaman peserta dari sebelum dilakukan kegiatan pengabdian edukasi keuangan syariah dengan sesudah pelaksanaan kegiatan. Tolok ukur keberhasilan kegiatan ini dapat dilihat dari aspek kualitatif dan kuantitatif berikut ini: (a) semua tahapan kegiatan pengabdian dapat terlaksana dengan baik; (b) pernyataan kepuasan dari peserta dan pihak-pihak yang terkait terhadap keseluruhan rangkaian kegiatan pengabdian; dan (c) sebesar $80 \%$ peserta yang diundang bisa hadir dalam setiap kegiatan pengabdian.

Beberapa tahapan pelaksanan edukasi keuangan syariah tersebut melibatkan partisipasi aktif mitra sasaran yakni siswa sekolah dasar di SD Muhammadiyah 8, 19 dan 24 Surabaya.

Tabel 1. Ragam media edukasi Keuangan Syariah

\begin{tabular}{|c|c|c|c|}
\hline Media & Tujuan Kegitan & Metode & \multirow{2}{*}{$\begin{array}{c}\text { Partisipasi Mitra } \\
\text { Mitra terlibat aktif untuk }\end{array}$} \\
\hline Komik Edukasi & Edukasi Tantang Bank & 1. Ceramah & \\
\hline Bank Syariah & Syariah & 2. Diskusi & membaca Komik \\
\hline Ular Tangga Cerdas & Edukasi & 1. Role Play & Mitra terlibat aktif untuk \\
\hline Keuangan Syariah & Menabung & 2. Diskusi & $\begin{array}{l}\text { mempraktekkan } \\
\text { permainan }\end{array}$ \\
\hline $\begin{array}{l}\text { Kartu si-Akad dan } \\
\text { Balok Akad }\end{array}$ & $\begin{array}{l}\text { Edukasi tentang ragam } \\
\text { akad dalam keuangan }\end{array}$ & $\begin{array}{l}\text { 1. Ceramah } \\
\text { 2. Role Play }\end{array}$ & $\begin{array}{l}\text { Mitra terlibat aktif } \\
\text { memainkan } 2 \text { permainan }\end{array}$ \\
\hline & syariah & 3. Diskusi & secara bersamaan \\
\hline Perbankan & Edukasi tentang ragam & 1. Ceramah & Mitra terlibat aktif untuk \\
\hline Syariah & $\begin{array}{l}\text { lembaga keuangan } \\
\text { syariah }\end{array}$ & 2. Diskusi & $\begin{array}{l}\text { mempraktekkan } \\
\text { permainan }\end{array}$ \\
\hline Perbankan & Edukasi tentang & 1. Ceramah & Mitra terlibat aktif untuk \\
\hline Syariah & perbankan syariah & 2. Role Play & mempraktekkan \\
\hline & & 3. Diskusi & permainan \\
\hline
\end{tabular}


Tabel 2. SDM Penelitian

\begin{tabular}{|c|c|c|c|c|}
\hline No & Pelaksana Kegiatan & Status Tim & Bidang Keahlian & $\begin{array}{c}\text { Pengalaman } \\
\text { Bidang } \\
\text { Keuangan } \\
\text { Syariah }\end{array}$ \\
\hline 1. & Arin Setiyowati & Ketua Pelaksana & Ekonomi Islam & Dosen \\
\hline 2. & Tiara Anindya V. & Anggota & $\begin{array}{l}\text { Perbankan } \\
\text { Syariah }\end{array}$ & Dosen \\
\hline 3. & Dian Lailatullailia & Anggota & $\begin{array}{l}\text { Perbankan } \\
\text { Syariah }\end{array}$ & Mahasiswa \\
\hline 4. & Ihyaul Hakiki & Anggota & $\begin{array}{l}\text { Perbankan } \\
\text { Syariah }\end{array}$ & Mahasiswa \\
\hline 5. & Partiningsih & Anggota & $\begin{array}{l}\text { Perbankan } \\
\text { Syariah }\end{array}$ & Mahasiswa \\
\hline
\end{tabular}

Pelaksanaan kegiatan program pengabdian masyarakat ini dapat menghasilkan output yang sesuai, maka kegiatan pengabdian ini didukung oleh SDM sesuai dengan keahliannya;

\section{HASIL DAN PEMBAHASAN}

\section{Tahapan Kegiatan Pengabdian}

Kegiatan pengabdian berupa literasi keuangan syariah untuk anak usia SD di lingkungan SD Muhammadiyah Surabaya, khususnya SD Muhammadiyah 19, 8 dan 24 Surabaya telah dilaksanakan dengan baik dan lancar. Adapun tahapan kegiatan pengabdian meliputi;

\section{Tahapan kegiatan perencanaan pengabdian}

Kegiatan perencanaan telah dilakukan koordinasi dengan kepala sekolah dan guru kelas yang ditunjuk untuk mengikutsertakan siswa-siswinya mengikuti kegiatan pameran literasi keuangan syariah. Adapun SD Muhammadiyah yang menjadi mitra pelaksanaan pengabdian literasi keuangan syariah adalah SD Muhammadiyah 8, 19 dan 24 Surabaya. Adapun masing-masing sekolah mendelegasikan 10 siswa-siswinya dengan rerata kelas 4-6. SD Muhammadiyah merupakan representasi dari sekolah Islam swasta yang dalam proses belajar-mengajarnya banyak menambahkan mata pelajaran Agama, namun dalam hal-hal muatan tema ekonomi, berdasarkan observasi awal pengabdi belum memasukkan muatan bahasan tentang ekonomi Islam maupun Keuangan Syariah. Selain itu, Sehingga SD Muhammadiyah menjadi mitra yang tepat untuk proses literasi keuangan syariah pada pengabdian ini.

Tim pengabdi menyampaikan maksud dan tujuan kepada kepala sekolah di masingmasing sekolah dan meminta izin serta arahan. Kemudian waktu dan tempat menjadi prioritas perencanaan serta identifikasi calon peserta kegiatan. Koordinasi pra pelaksanaan kegiatan terlaksanana dua kali dengan kepala sekolah dan guru. Calon peserta kegiatan literasi yang akan diundang adalah siswa kelas 4, 5 dan 6 baik di SD Muhammadiyah 8, 19, dan 24 Surabaya sejumlah 10 untuk masing-masing sekolah.

\section{Tahapan kegiatan pelaksanaan pengabdian}

Kegiatan pengabdian dilaksanakan pada Selasa, 30 Oktober 2019 pukul 13.00 WIB sd selesai di lapangan futsal kampus UMSurabaya. Kegiatan diikuti 30 orang peserta, terdiri dari masing-masing 10 siswa-siswi dari SD Muhammadiyah 19, 8 dan 24 Surabaya. Beberapa peserta dari SD Muhammadiyah lain yang telah menyatakan kesediaan hadir, 
tidak bisa mengikuti kegiatan pengabdian dikarenakan ada keperluan lain. Pelaksanaan kegiatan pengabdian dibantu 3 orang mahasiswa, yaitu Dian, Haqi dan Parti.

Kegiatan diawali dengan pengenalan dan briefing awal tentang ragam media edukasi yang dimainkan dan diedukasikan kepada peserta oleh tim pengabdi. Dilanjutkan dengan pembagian regu untuk memainkan masing-masing media edukasi yakni kartu si-akad, komik, puzzle, diorama dan ular tangga. Dilanjutkan dengan pengantar dari tim pengabdi yang memberikan materi berupa gambaran umum tentang sistem ekonomi Islam dan khususnya keuangan syariah. Yang diwakili oleh Arin Setiyowati, SHI., MA.

Pengabdi menyampaikan beberapa pertanyaan awal untuk mengetahui pemahaman awal dari peserta. Beberapa peserta telah memahami lembaga keuangan syariah (akad dan produk- produk perbankan syariah), sementara yang lainnya masih belum begitu mengenal. Narasumber kemudian menyampaikan materi yang telah disiapkan, diantaranya mengenai konsep dasar ekonomi syariah, perbedaan perbankan syariah dengan perbankan konvensional, prinsip keuangan Islam, dan akad-akad yang digunakan dalam transaksi lembaga keuangan syariah. Kegiatan dilanjutkan dengan tanya jawab.

Kemudian peserta menuju masing-masing stand media edukasi yang telah disiapkan untuk dimainkan, diedukasi oleh tim pengabdi dan didiskusikan bersama. Setelah itu, masingmasing penanggungjawab media edukasi mengajukan pertanyaan evaluative akan tingkat pemahaman peserta atas konten edukasi keuangan syariah yang telah disampaikan oleh tim pengabdi di masing-masing stand media edukasi meliputi ;

a. Literasi Keuangan Syariah melalui Media Kartu si-Akad

b. Literasi Keuangan Syariah melalui Media Komik Pintar Keuangan Syariah

c. Literasi Keuangan Syariah melalui Media Puzzle

d. Literasi Keuangan Syariah melalui media Diorama

e. Literasi Keuangan Syariah melalui media ular tangga

Setelah semua stand media edukasi dilalui, dilaksanakan evaluasi massal yang ada rewardnya. Kebetulan dalam kegiatan pengabdian ini, tim menggandeng salah satu perbankan syariah yang memiliki kantor cabang pembantu di kampus, yakni BNI Syariah. Sehingga di sesi evaluasi ini menjadi pamungkas pada rangkaian kegiatan pengabdian literasi keuangan syariah kepada para siswa usia SD, yakni siswa-siswi SD Muhammadiyah di Surabaya.

Adapun beberapa pertanyaan yang diajukan tim pengabdi bersama tim BNI Syariah kepada peserta dalam rangka untuk mengetahui pemahaman mengenai materi yang disampaikan. Beberapa peserta telah cukup paham mengenai lembaga keuangan syariah secara dasar, khususnya akad-akad yang digunakan lembaga keuangan syariah. Namun demikian, perlu ditingkatkan lagi mengenai aplikasi akad-akad tersebut dalam produk perbankan syariah modern. Kegiatan ditutup pada pukul 15.00 dan dilanjutkan dengan shalat ashar. 


\section{Tahapan kegiatan evaluasi pengabdian}

Tahapan kegiatan evaluasi dilakukan dengan tujuan ; (1) evaluasi proses pelaksanaan kegiatan pengabdian literasi keuangan syariah kepada anak usia SD, yakni siswa-siswa SD Muhammadiyah 19, 8 dan 24 Surabaya. dan (2) evaluasi peningkatan pemahaman peserta mengenai literasi keuangan syariah. evaluasi proses kegiatan pengabdian telah dilakukan dengan melihat jumlah peserta yang hadir, keseriusan peserta dalam mengikuti kegiatan literasi keuangan syariah. Keseluruhan indikator menunjukkan bahwa kegiatan pengabdian ini dapat dilaksanakan dengan sukses dan lancar. Para peserta menyatakan antusiasmenya pada ragam media edukasi, transformasi pengetahuan dan pemahaman akan keuangan syariah telah menunjukkan hasil yang signifikan.

Tim pengabdi telah melaksanakan evaluasi kedua mengenai peningkatan literasi keuangan syariah. Dengan cara membandingkan pemahaman awal sebelum pemaparan materi dan setelah pemaparan. Hasilnya menunjukkan terdapat peningkatan yang cukup signifikan mengenai pemahaman akad-akad yang digunakan lembaga keuangan syariah dan mengetahui perbedaan bank syariah dan bank konvensional.

\section{Pembahasan}

Perkembangan kajian maupun implementasi ekonomi syariah menjadi fenomena penting yang mampu mempengaruhi perekonomian Indonesia. Khususnya lembaga keuangan syariah. Lebih tepatnya perbankan syariah di Indonesia mendapatkan respon positif dan akan terus berkembang. Perkembangan positif ini perlu didukung dengan proses internalisasi hingga sosialisasi massif kepada seluruh masyarakat, sehingga akan menjadi lebih baik ke depannya jika dikenalkan kepada masyarakat sejak usia dini. Tanpa terkecuali jika dimasukkan dalam kurikulum sekolah formal pada level Sekolah Dasar (SD). Mengingat usia golden age pada jenjang sekolah dasar menjadi sangat penting dan mendasar untuk memberikan bekal bagi siswa-siswa SD untuk lebih dini mengenal keuangan syariah. Khususnya di lingkungan SD Muhammadiyah. Melalui media edukatif, guru-guru dapat mengenalkan dan memberikan pemahaman dengan kondisi pembelajaran yang sangat kreatif dan kondusif. Kenyataannya, kegiatan edukasi yang dilakukan selama ini untuk meningkatkan literasi keuangan syariah masih lemah. Dan belum bisa menyentuh kalangan pendidikan dasar, yakni anak usia sekolah dasar di jengjang sekolah formal, khususnya SD Muhammadiyah di Surabaya.

Pembentukan pemahaman dan kecakapan peserta didik dalam hal pengetahuan dan penerapan ekonomi syariah sesuai bidang yang diperlukan dalam kehidupan. Tujuan Literasi ekonomi syariah adalah untuk :(Kusumadewi, Yusuf, and Si, M 2019)

1. Memberikan bekal pemahaman ekonomi syariah sejak dini melalui pendidikan dasar sehingga terbentuk mindset ekonomi Islam kepada masyarakat Islam khususnya pada anak-anak usia pendidikan dasar.

2. Memberikan bekal kemampuan untuk bertindak terkait dengan keperluan aktifitas ekonomi syariah, baik terkait dengan bisnis maupun jasa keauangan dalam kehidupan sehari-hari.

3. Memperluas dan meningkatkan pengetahuan, pemahaman dan peran serta masyarakat dalam penggunaan produk dan jasa keuangan syariah. 
4. Tidak hanya mampu meningkatkan pengetahuan masyarakat, tetapi juga mengubah prilaku masyarakat dalam mengelola keuangan secara lebih baik, mampu dan cerdas memilih investasi yang halal dan menguntungkan,

5. Memberikan kemampuan mencegah masyarakat mengikuti investasi bodong yang kerap muncul di tengah masyarakat. Pada umumnya pengelolaan keuangan anak pada usia pendidikan dasar untuk pos penerimaan harta dapat diperoleh melalui bekerja, berdagang, hadiah dan pemberian nafaqoh dari orang tua guna

Berangkat dari fenomena tersebutlah menjadi landasan pelaksanaan kegiatan pengabdian ini. Dan tim pengabdi ingin berkontribusi meningkatkan literasi keuangan syariah bagi anak usia sekolah dasar (SD). Pelaksanaan kegiatan pengabdianmenunjukkanbahwabelum banyak materi-materi pelajaran di sekolah yang secara tersurat mengedukasi tentang segala hal berkaitan dengan keuangan syariah, misalnya tentang akad-akad yang digunakan dalam bank syariah sehingga menjadi pembeda dengan bank konvensional. Beberapa istilah masih asing dikenal. Konsep dasar keuangan syariah juga masih menunjukkan pemahaman yang belum memadai dari beberapa peserta kegiatan. Perbedaan bank syariah dan bank konvensional hanya dipahami bank dengan bungan dan non bunga.

Pada masing-masing media edukasi telah memiliki spesifikasi konten edukasi keuangan syariah sebagaimana berikut ;

- Media Kartu si-Akad, memiliki konten edukasi akad-akad dalam keuangan syariah, khususnya perbankan syariah.

- Media Diorama Perbankan Syariah, memiliki konten edukasi ragam lembaga keuangan syariah.

- Media Puzzle, memiliki konten edukasi Keuangan syariah

- Media komik, memiliki konten edukasi tentang perbankan syariah yang dikemas dalam bentuk cerita bergambar komik.

- Media ular tangga, memiliki konten edukasi tentang cerdas mengelola keuangan secara bijak dan Islami, dengan kemasan permainan yang mengkombinasikan antara motprik dan kognitif peserta.

Selain itu ditambah dengan penjelasan gambaran umum dari tim pengabdi tentang materi awal mengenai pengenalan keuangan syariah, lembaga keuangan syariah dan akadakad yang digunakan dalam keuangan syariah dengan baik. Peserta dapat mengenal beberapa bentuk lembaga keuangan syariah selain bank.

Kegiatan pengabdian ini perlu ditindaklanjuti dengan kegiatan berikutnya, yaitu bagaimana proses menginternalisasikan materi-materi tentang ekonomi syariah khususnya keuangan syariah ke dalam text book maupun menjadi pembelajaran tema tersendiri dalam kurikulum sekolah dasar. Hal ini menarik karena edukasi keuangan syariah akan menyentuh pada usia dini. Dan tentunya bukan hal yang mudah untuk dilaksanakan, maka sangat dibutuhkan kreatifitas guru sekolah dasar.

Pelaksanaan kegiatan pengabdian secara umum dapat berjalan dengan baik dan lancar. Hal ini dikarenakan dukungan yang diberikan oleh pihak mitra, yakni SD Muhammadiyah 8, 19, dan 24 Surabaya. Selain itu didukung oleh BNI Syariah Kcp Dharmawangsa Surabaya yang berada di kampus UMSurabaya. Kegiatan dilaksanakan di tempat yang sangat memadai 
dan diikuti dengan cukup banyak peserta. Fasilitas yang tersedia dapat mendukung pelaksanaan kegiatan pengabdian. Partisipasi aktif siswa-siswi SD Muhammadiyah 8, 19 dan 24 Surabaya sebagai peserta pada kegiatan pengabdian literasi keuangan syariah juga menjadi faktor kesuksesan kegiatan pengabdian ini. Yang mana dibuktikan dengan ditunjukkan kehadiran dan partisipasi aktif saat/proses pelaksanaan kegiatan pengabdian.

\section{KESIMPULAN}

Berdasarkan uraian hasil pelaksanaan kegiatan pengabdian dan pembahasan, simpulan yang dapat ditarik adalah sebagai berikut ;

- Kegiatan pengabdian kepada masyarakat dapat dilaksanakan dengan baik dan lancar. Terdiri dari tiga tahapan pelaksanaan, yaitu perencanaan, pelaksanaan dan evaluasi kegiatan. Kegiatan pengabdian diikuti 30 siswa-siswi SD Muhammadiyah 8, 19 dan 24 Surabaya.

- Kegiatan pengabdian kepada masyarakat melalui edukasi keuangan syariah dengan media edukasi berupa kartu si-akad, diorama, puzzle, komik dan ulartangga terbukti signifikan dapat meningkatkan literasi keuangan syariah peserta kegiatan. Hal ini ditunjukkan dengan semakin pahamnya peserta mengenai konsep dasar keuangan syariah khususnya perbankan syariah dan akad-akad yang digunakan untuk pengembangan produk lembaga keuangan syariah.

\section{UCAPAN TERIMAKASIH}

Terima Kasih kami sampaikan kepada pihak SD Muhammadiyah 8, 19 dan 24 Surabaya yang telah bersedia menjadi mitra dalam kegiatan pengabdian ini. Serta partisipasi aktifnya sehingga kegiatan pengabdian berjalan dengan lancer dan baik.

\section{DAFTAR PUSTAKA}

OECD INFE (2011) Measuring Financial Literacy: Core Questionnaire in Measuring Financial Literacy: Questionnaire and Guidance Notes for conducting an Internationally Comparable Survey of Financial literacy. Paris: OECD, 2011, hal. 3.

Asyhad, M dan Handono, WA. 2017. "Urgensi Literasi Keuangan Syari'ah Pada Pendidikan Dasar." Miyah 13 (01): 12643.

Kusumadewi, Rita, H Ayus Ahmad Yusuf, and Wartoyo Si, M. 2019. Literasi Keuangan Syariah Di Kalangan Pondok Pesantren. Februari 2. CV. ELSI PRO.

Said, Salmah, and Andi Muhammad Ali Amiruddin. 2017. "Literasi Keuangan Syariah Di Perguruan Tinggi Keagamaan Islam ( Studi Kasus UIN Alauddin Makasar ) Salmah Said Dan Andi Muhammad Ali Amiruddin Universitas Islam Negeri Alauddin Makassar Keywords : Literasi , Keuangan, Islam, Perguruan Tinggi , UIN Alaud." Al-Ulum 17 (1): 44-64. https://doi.org/10.9744/ jmk.17.1.76.

Subardi, Hani Meilita Purnama, Yuliafitri, Indri. 2019. "Efektivitas Gerakan Literasi Keuangan Syariah Dalam Mendedukasi Masyarakat Memahami Produk Keuangan Syariah." Banque Syar'i : Jurnal Ilmu Perbankan Syariah 5: 31-44. 